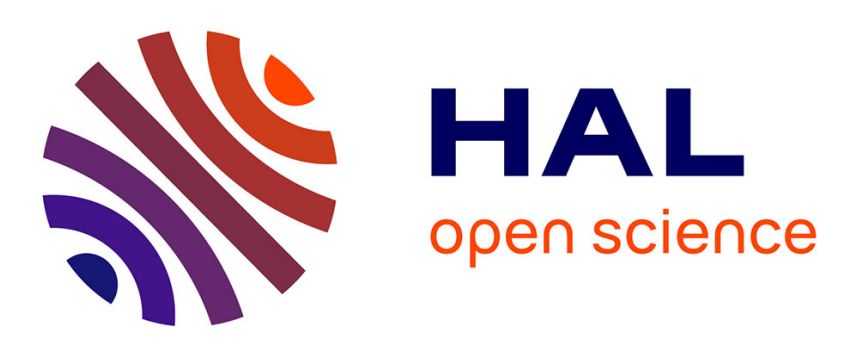

\title{
rRNA sequence comparison of Beauveria bassiana, Tolypocladium cylindrosporum, and Tolypocladium extinguens
}

\author{
Malalanirina S Rakotonirainy, M. Dutertre, Y. Brygoo, G. Riba
}

\section{To cite this version:}

Malalanirina S Rakotonirainy, M. Dutertre, Y. Brygoo, G. Riba. rRNA sequence comparison of Beauveria bassiana, Tolypocladium cylindrosporum, and Tolypocladium extinguens. Journal of Invertebrate Pathology, 1991, 57 (1), pp.17-22. 10.1016/0022-2011(91)90036-P . hal-02947898

\section{HAL Id: hal-02947898 \\ https://hal.science/hal-02947898}

Submitted on 29 Sep 2020

HAL is a multi-disciplinary open access archive for the deposit and dissemination of scientific research documents, whether they are published or not. The documents may come from teaching and research institutions in France or abroad, or from public or private research centers.
L'archive ouverte pluridisciplinaire HAL, est destinée au dépôt et à la diffusion de documents scientifiques de niveau recherche, publiés ou non, émanant des établissements d'enseignement et de recherche français ou étrangers, des laboratoires publics ou privés. 


\title{
rRNA Sequence Comparison of Beauveria bassiana, Tolypocladium cylindrosporum, and Tolypocladium extinguens
}

\author{
M. S. Rakotonirainy, ${ }^{*}$ M. Dutertre, $†$ Y. Brygoo, $\dagger$ and G. Riba* \\ *Institut National de la Recherche Agronomique, Biological Control Research Station, La Minière 78280 \\ Guyancourt, France, and tLaboratoire de Cryptogamie, Université Paris XI, 91405 Orsay, France
}

Received November 20, 1989; accepted April 13, 1990

Five strains of Tolypocladium cylindrosporum, one strain of Tolypocladium extinguens, and nine strains of Beauveria bassiana were analyzed using a rapid rRNA sequencing technique. The sequences of two highly variable domains (D1 and D2) located at the 5 ' end of the 28S-like rRNA molecule were determined. The phylogenetic tree computed from the absolute number of nucleotide differences shows the separation between the genus Beauveria and the genus Tolypocladium and points out that $T$. cylindrosporum and $T$. extinguens probably do not belong to the same genus. 1991 Academic Press, Inc.

\section{INTRODUCTION}

The morphoontogenic criteria generally used for the determination of the genus and species of filamentous Fungi sometimes raise controversy. Thus, the genus Tolypocladium (Gams, 1971) was recently integrated with the genus Beauveria (Von Arx, 1986) based on the morphological similarities.

In the Hyphomycete genus Tolypocladium, two entomopathogenic species are known: Tolypocladium cylindrosporum and Tolypocladium extinguens, which are distinguished by the morphological structure (Samson and Soares, 1984) as well as by their isoenzymatic profiles (Soares et al., 1985).

The phyletic relationship which exists between the group Tolypocladium and the group Beauveria can be studied by the analysis of the sequences of the 28S rRNA subunit. In fact, ribosomal RNAs (rRNAs) provide a powerful taxonomic indicator since they are highly conserved in living organisms. The 5S rRNA, too short, has been much more rapidly evolving domains (D1 and D2) (Clark et al., 1984).

A comparative analysis of the sequences of these regions (D1 and D2) has been undertaken for several isolates of $T$. cylindrosporum, $T$. extinguens, and $B$. bassiana in order to get an idea of the phylogenetic relationship among these species.

\section{MATERIALS AND METHODS}

\section{Fungal Strains}

All strains used in this study originated from the fungal collection of the biological Control Research Station of La Minière, INRA (Table 1).

\section{Growth Conditions and Preparation of $28 S$ rRNA}

Fungi were grown at $25^{\circ} \mathrm{C}$ on a semisynthetic (CM) agar or liquid medium containing the following: $0.4 \mathrm{~g}$ of $\mathrm{KH}_{2} \mathrm{PO}_{4} ; 1.4 \mathrm{~g}$ of $\mathrm{NA}_{2} \mathrm{HPO}_{4}, 2 \mathrm{H}_{2} \mathrm{O} ; 0.6 \mathrm{~g}$ of $\mathrm{Mg} \mathrm{SO}_{4}, 7 \mathrm{H}_{2} \mathrm{O} ; 1$ $\mathrm{g}$ of $\mathrm{KCl} ; 0.7 \mathrm{~g}$ of $\mathrm{NH}_{4} \mathrm{NO}_{3} ; 10 \mathrm{~g}$ of glucose, $5 \mathrm{~g}$ of yeast extract; and $20 \mathrm{~g}$ of agar in 1000 $\mathrm{ml}$ of distilled water. 
TABLE 1

List of SEquenced Strains

\begin{tabular}{llllr}
\hline \multicolumn{1}{c}{ Species } & Isolate & \multicolumn{1}{c}{ Host species } & \multicolumn{1}{c}{$\begin{array}{c}\text { Geographical } \\
\text { origin }\end{array}$} & Date \\
\hline Beauveria hassiana & Bb 28 & Leptinotarsa decemlineata & France & 1971 \\
& Bb 70 & Lasiocampidae & Madagascar & 1973 \\
& Bb 73 & & USRR & 1974 \\
& Bb 103 & Gargaphia sp. & Colombia & 1975 \\
& Bb 147 & Ostrinia nubilalis & France & 1978 \\
& Bb 169 & Sitona discoideus & France & 1981 \\
& Bb 182 & Sitona discoideus & France & 1982 \\
& Bb 216 & Sitona discoideus & Morocco & 1983 \\
& Bb 377 & Ostrinia nubilalis & France & 1986 \\
& TC 1 & Aedes sierrensis & United States & 1971 \\
& TC 7 & Aedes australis & New Zealand & $?$ \\
& TC 8 & Fern & England & 1965 \\
& TC 9 & Soil & Holland & $?$ \\
Tolypocladium extinguens & TC 10 & Soil & Czechoslovakia & 1967 \\
& TC 16 & Arachnocampa luminosa & New Zealand & 1977
\end{tabular}

washed with sterile water, lyophilized, and stored at $-20^{\circ} \mathrm{C}$. Mycelium (120 mg) of each lyophilized strain was powdered in liquid nitrogen and soaked in $1 \mathrm{ml}$ of an extraction

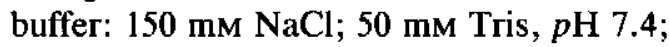
5 mM EDTA, and 5\% sodium dodecyl sulfate.

Nucleic acids were extracted and purified twice with $1 \mathrm{ml}$ of a solution of phenol:chloroform (1:1). Samples were centrifuged for $15 \mathrm{~min}$ at $10,000 \mathrm{~g}$ during each extraction. A series of precipitation with $\mathrm{LiCl}$ (4 and $2 \mathrm{M}$ ) and ethanol permitted the samples to be washed, eliminating double-stand DNA.

\section{rRNA Sequencing}

The dideoxynucleotide chain termination method was used, modified for the use of reverse transcriptase ( $Q u$ et al., 1983). RNA synthesis was initiated using standard synthetic oligonucleotide primers (P1, P3) $5^{\prime}$ end labeled with $\gamma$ P32 ATP and polynu- which has also been sequenced using a third primer $(\mathrm{P} 2)$.

Nucleotide fragments were separated by gel electrophoresis (6 and $8 \%$ ) polyacrylamide in Tris-borate buffer. Gels were dryed before autoradiography and revealed after 3 days of exposure in Amersham film.

\section{Analysis of Data}

For each domain, the sequences were aligned manually and each one was compared with the others. Dendrograms were constructed by using the Fitch program of Felsenstein's Phylip package. This method translates directly punctual differences observed in phyletic distances measured in terms of the proportions of different nucleotides (Fitch and Malgoliash, 1967).

One approach by the parsimonious method was also studied using the DNA PENNY program from the same package. Parsimony selects the trees that require the minimum of events. One strain of Fusarium

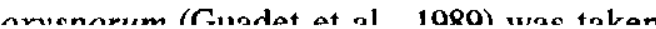


in three distinct groups. The first comprises all the strains of $T$. cylindrosporum, the second comprises the strains of $B$. bassi$a n a$, and the third consists of one strain of $T$. extinguens. The sequences of the strains which comprise each group are strictly identical, regardless of the geographical origin and the host species. The three groups of sequences are sufficiently homologous to enable them to be aligned (Fig. 1).

The region we selected, about 500 nucle- otides long, should provide enough data and should reduce the risk of spurious fluctuations in the statistics of nucleotide substitutions. The substitution of nucleotides constitutes the type of variation most often observed. As already observed in other organisms, the differences are particularly concentrated in the domain D2. The nature and the position of the majority of the substitutions between $T$. extinguens and $B$. bassiana are also found between $T$. cylin-
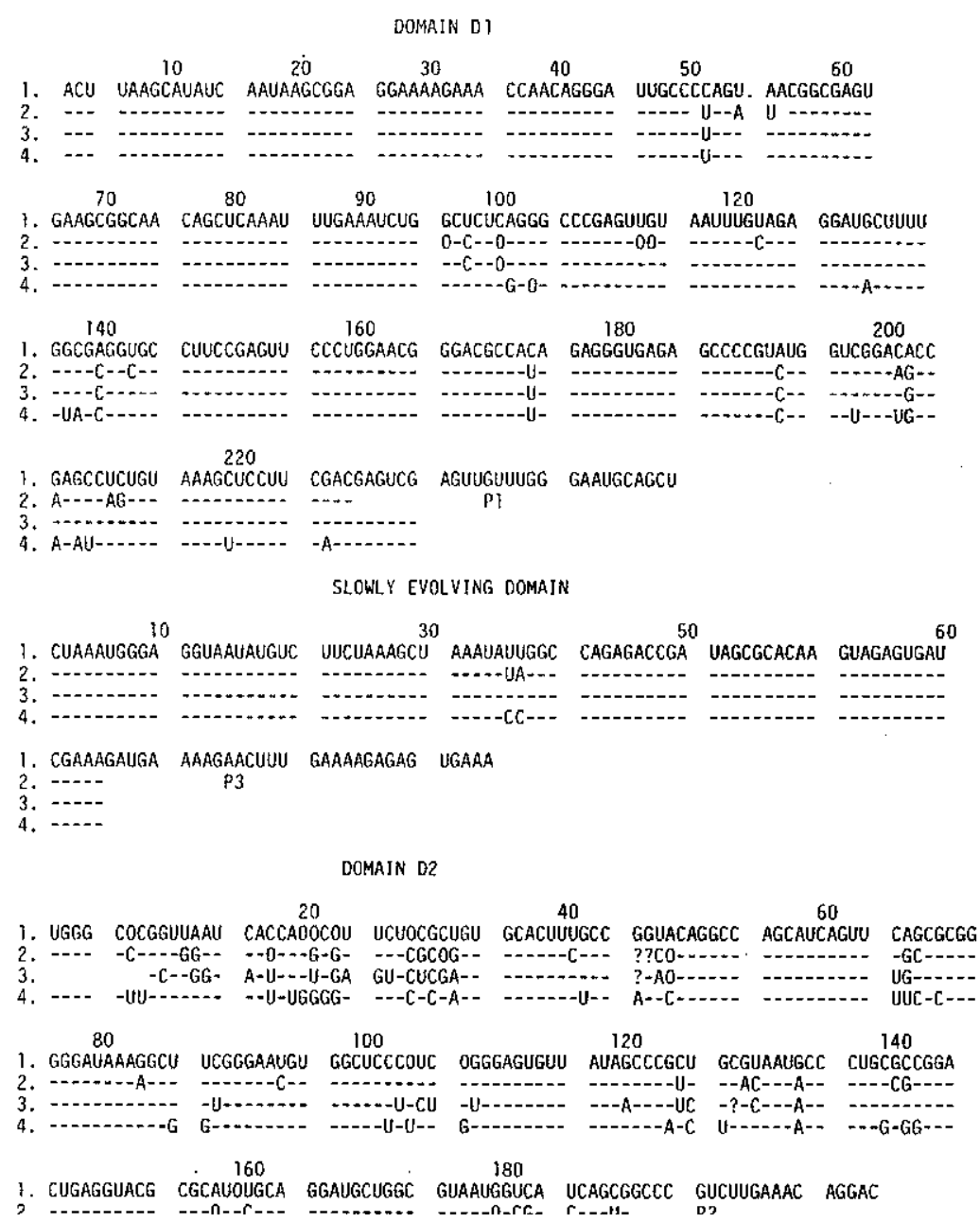
TABLE 2

Distance Matrix among the Three Classes of Identical Sequences, Plus One REFERENCE SPECIES: Fusarium oxysporum

\begin{tabular}{lcccc}
\hline & $\begin{array}{c}B . \text { bassiana } \\
(\mathrm{Bb})\end{array}$ & $\begin{array}{c}\text { T. cylindrosporum } \\
(\mathrm{Tc})\end{array}$ & $\begin{array}{c}\text { T. extinguens } \\
(\mathrm{Te})\end{array}$ & $\begin{array}{c}\text { F. oxysporum } \\
(\mathrm{Fo})\end{array}$ \\
\hline $\mathrm{Bb}$ & - & 51 & 39 & 47 \\
$\mathrm{Tc}$ & 0.315 & - & 47 & 65 \\
$\mathrm{Te}$ & 0.234 & 0.287 & - & 57 \\
Fo & 0.291 & 0.418 & 0.359 & - \\
\hline
\end{tabular}

Note. Distances are expressed in absolute value of differing bases (up per matrix) within the D1 + D2 regions and in lower matrix the corresponding knuc value.

drosporum and B. bassiana. Within D1, containing 227 nucleotides, 18 sites of substitutions or deletions were denoted and 48 within the 190 sequenced nucleotides of D2 and finally only two substitutions were observed in the evolutionarily conserved region.

A representative comparison by a distance matrix is shown in Table 2 . Only the two domains D1 and D2 have been taken into account. It appears that variation of D1 and $\mathrm{D} 2$ between $T$. cylindrosporum and $B$. bassiana is greater than that between $B$. bassiana and $T$. extinguens. The differences between $B$. bassiana and $T$. cylindrosporum is as important as that between $B$. bassiana and $F$. oxysporum.

The dendrograms (Fig. 2) produced by the two selected programs give a better understanding of the phyletic relationship among the four groups of sequences. The two approaches give the same topology. The dendrogram shown in Figure 2 was derived using the Fitch program of the Phylip package. Branch lengths were obtained with crude distance values without modification.

$T$. extinguens is relatively closer to $B$. bassiana than to T. cylindrosporum. Conversely, $T$. cylindrosporum is very different from $T$. extinguens and from $B$. bassiana. $B$. bassiana is as distant from $T$. cylindrosporum as from $F$. oxysporum. However, the latter is taken as an outgroup species. It is evident that the three groups are really very distinct.

\section{DISCUSSION}

$T$. cylindrosporum has been characterized by Von Arx (1986) as the synonym $B$. cylindrospora on the structural similarities of conidiogenous elements and the appearance of the colonies. Several authors have : questioned the validity of this arrangement (Mugnai et al., 1989; Samson et al., 1988).

The two genera Tolypocladium and Beauveria, despite a similarity in certain morphological structures, have important

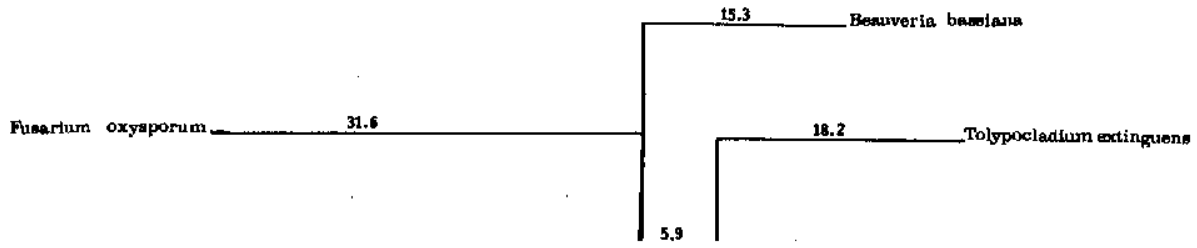


TABLE 3

Comparison of Different Morphological Characters of the Three Groups

\begin{tabular}{|c|c|c|c|}
\hline $\begin{array}{l}\text { Conidiogenous } \\
\text { cells production }\end{array}$ & $\begin{array}{c}\text { Beauveria bassiana } \\
\text { Sympodial }\end{array}$ & $\begin{array}{c}\text { Tolypocladium } \\
\text { cylindrosporum } \\
\text { Basipetal }\end{array}$ & $\begin{array}{c}\text { Tolypocladium } \\
\text { extinguens } \\
\text { Basipetal }\end{array}$ \\
\hline $\begin{array}{l}\text { Structure of } \\
\text { Conidiophores }\end{array}$ & $\begin{array}{c}\text { Not in sporodochia, } \\
\text { without stipe and } \\
\text { swollen vesicles }\end{array}$ & $\begin{array}{l}\text { Verticillate branches } \\
\text { bearing lateral or } \\
\text { terminal whorls of } \\
\text { phialides }\end{array}$ & $\begin{array}{c}\text { Bearing several regularly } \\
\text { verticillates branches } \\
\text { which terminate in } \\
\text { whorls on phialides }\end{array}$ \\
\hline Phialides & Absent & $\begin{array}{l}\text { With swollen cylindrical } \\
\text { base }\end{array}$ & $\begin{array}{l}\text { Small with swollen base } \\
\text { and a thin neck }\end{array}$ \\
\hline Conidia & $\begin{array}{l}\text { Different shape, one } \\
\text { celled, globose }\end{array}$ & $\begin{array}{l}\text { Cylindrical with rounded } \\
\text { ends, often slightly } \\
\text { bent }\end{array}$ & Subglobose to ellipsoidal \\
\hline $\begin{array}{l}\text { Conidiogenous } \\
\text { cells }\end{array}$ & $\begin{array}{l}\text { Smooth-walled, flask } \\
\text { shaped with a swollen } \\
\text { basal part terminating } \\
\text { in a zig-zag rachis }\end{array}$ & & \\
\hline
\end{tabular}

ontogenic differences, notably due to the fact that Beauveria has sympodial conidiogenis while that of Tolypocladium is basipetal (Table 3). Additionally, the molecular approach by the analysis of rRNA sequences enhances the differences between the genus Tolypocladium and the genus Beauveria. Moreover, the rRNA sequences show that the differences between $T$. extinguens and $T$. cylindrosporum are almost as great as the differences between the genus Tolypocladium and the genus Beauveria (Table 2 ; There are 47 variations between $T$. extinguens and $F$. oxysporum and 51 between $B$. bassiana and $T$. cylindrosporum). Since the rRNA of $T$. cylindrosporum, $T$. extinguens, and $B$. bassiana are as different between each other as they are from Fusarium (ex. 51 variations between T. cylindrosporum and B. bassiana and 47 between $B$. bassiana and $F$. oxysporum), we suggest on the one hand that the genus Beauveria and the genus Tolypocladium are not related and on the other hand that $T$. cylindrosporum and T. extinguens probably used for the determination of $T$. cylindrosporum and T. extinguens does not have phylogenetic significance. Moreover, T. extinguens is weakly virulent against mosquitoes species while strains of $T$. cylindrosporum are highly virulent.

In conclusion, the rRNA polymorphisms, the isozymes variability, and the morphoontogenic characters have complementary data from where we conclude the separation between the genus Beauveria and the genus Tolypocladium.

\section{REFERENCES}

Baroin, A., Perasso, R., Qu, L. H., Brugerolle, G., Bachellerie, J. P., And Adoutte, A. 1988. Partial phylogeny of the unicellular eukaryotes based on rapid sequencing of a portion of the $28 \mathrm{~S}$ rRNA. Proc. Natl. Acad. Sci. USA, 85, 3474-3478. Clark, C. G., Tague, B. W., Wassie, C. W., and GerBI, S. A. 1984. Xenopus laevis $28 \mathrm{~S}$ ribosomal RNA: A secondary structure model and its evolutionary and functional implications. Nucleic Acids Res., 12, 6197-6220.

Fitch, W. M., ANd Margoliash, E. 1967. Construction of phylogenetic trees. Science, 155, 279-284.

GAMs, W. 1971. Tolypocladium, eine Hyphomyceten- 
A chemotaxonomic evaluation of the genus Beakveria. Mycol. Res., 92(2), 199-209.

QU, T. H., Michot, B., AND Bachellerie, J. P. 1983. Improved methods for structure probing in large RNAs: A rapid "heterologous" sequencing approach is coupled to the direct mapping of nuclease accessible sites: Application to the 5' terminal domain of eukaryotic $28 \mathrm{~S}$ rRNA. Nucleic Acids Res., 11, 5903-5920.

QU, T. H., Nicoloso, M., AND Bachellerie, J. P. 1988. Phylogenetic calibration of 5 ' terminal domain of large rRNA achieved by determining twenty eucaryotic sequences. J. Mol. Evol., 28, 113-124.

Salim, M., and Maden, B. E. H. 1981. Nucleotide sequence of Xenopus laevis $18 \mathrm{~S}$ ribosomal RNA in- ferred from gene sequence. Nature (London), 291, 205-208.

Samson, R. A., and Soares, G. G. 1984. Entomopathogenic species of the Hyphomycete genus Tolypocladium. J. Invertebr. Pathol., 43, 133-139.

Samson, R. A., Evans, H. C., and Latge, J. P. 1988. "Atlas of Entomopathogenic Fungi." Springer-Verlag, New York/Berlin.

Soares, G. G., Riba, G., Caudal, A., and VinCENT, J. J. 1985. Comparative studies of eleven isolates of the fungal entomopathogen Tolypocladium cylindrosporum and two isolates of Tolypocladium extinguens. J. Invertebr. Pathol., 46, 115-120.

Von ARX, J. A. 1986. Tolypocladium, a synonym of Beauveria. Mycotaxon, 25, 153-158. 